\title{
C
}

\section{British Ecological Society}

Vorschlag zur Nomenklatur der Soziologischen Pflanzengeographie. by C. E. Du Rietz; Th. C. E. Fries; T. A. Tengwall

Journal of Ecology, Vol. 7, No. 1/2 (May, 1919), pp. 100-101

Published by: British Ecological Society

Stable URL: http://www.jstor.org/stable/2255726

Accessed: 25/06/2014 04:48

Your use of the JSTOR archive indicates your acceptance of the Terms \& Conditions of Use, available at http://www.jstor.org/page/info/about/policies/terms.jsp

JSTOR is a not-for-profit service that helps scholars, researchers, and students discover, use, and build upon a wide range of content in a trusted digital archive. We use information technology and tools to increase productivity and facilitate new forms of scholarship. For more information about JSTOR, please contact support@jstor.org.

British Ecological Society is collaborating with JSTOR to digitize, preserve and extend access to Journal of Ecology. 
these biocoenosia: indeed he scarcely takes cognisance of the ecological factors which unite and separate the smaller topographical units. The practical difficulty comes in when we attempt to separate the author's third grade of synusia, the components of which "durch feste Korrelationen zu einer ökologischen Einheit auf einem einheitlichen Standort verbunden sind," from what the author regards as purely topographical units. The whole difference depends, as will be seen, on the degree of correlation. The word "feste" rather begs the question. Whether the distinction, logically sound though it is, will be useful in practice, remains to be seen.

The author gives a new classification of life forms, largely based on Raunkiaer's system, but extended and including animals. This appears to be the best which has yet been published.

Du Rietz, C. E. "Några synpunkter på den synekologiska vegetationsbeskrifningens terminologi och methodik." Svensk Botanisk Tidskrift, 11,1917 , pp. 51-71, with a German résumé.

In this paper the author puts forward several new terms and provides definitions for several old ones. His general standpoint is that of the paper noticed below, and his terminology may be considered as superseded by that proposed by the joint authors.

\section{Du Rietz, C. F., Fries, Th. C. F., and Tengwall, T. Å. "Vorschlag zur Nomenklatur der soziologischen Pflanzengeographie." Svensk Botanisk Tidskrift, 12, 1918, pp. 145-170.}

This paper sets out to expound, modify and summarise the ideas originating with Hult (1881) and Sernander, who worked on Finnish vegetation, and recently developed by Fries and Du Rietz in Sweden. The authors lay stress on the separateness of the FinnishSwedish school of ecologists from the workers in the rest of the world, and claim that the former was marked by true 'inductive' methods at a time when extra-Swedish study of vegetation was suffering from a conflict between confused 'inductive' principles and the 'deductive' principles introduced by Schouw, Thurmann and Sendtner. They insist that the plant-association must be characterised by the composition of the vegetation alone, i.e. by definite floristic composition, and that the factors which give rise to associations must not be introduced into the definition, and combat the views of Samuelsson and Melin, who include in the same association similar "Bestände" which may have no species in common. The authors proceed to call attention to the historical factor, which, together with the 'ecological' (habitat conditions) and the biotic, helps to determine the associations actually existing in a given area. Thus successful invasion by a foreign species may occur without any alteration of the habitat, and several associations may exist side by side in the same habitat.

All this of course is perfectly true, but the authors seem to ignore the range of conditions within which an association can exist, which is an essential datum for determining what may be called the ecological constants of the association. The whole paper seems vitiated by the belief that 'inductive' is synonymous with 'descriptive.' The authors rightly contend for an accurate floristic characterisation and limitation of the association, but one of the main objects of synecology is surely to define the conditions under which given associations develop, exist and die out. If that can be accurately done it forms part of the characterisation of the association, and to stigmatise all attempts to take the habitat into consideration in classifying vegetation as the employment of 'deductive' methods appears to be a simple misuse of language. We fully agree however that the association must in the first instance be defined by its floristic composition, and not by habitat, and 


\section{Notices of Publications of General Bearing}

that to name an association as the association of such and such a habitat is to begin at the wrong end. Some of the newer definitions of synecological terms given by the authors may be summarised as follows:

Association-fragment. A plant-community which cannot form an elementary association on account of restriction of the, habitat.

Facies. Various forms of an association due to geographical position.

Variants. Deviations of associations due to other than geographical causes.

Association-complex. A union of associations or fragments of associations to a phytogeographical unit. (Cf. Nichols's use of the same term, p. 102 below).

Twin-associations (Zwillingsassoziationen). Associations floristically and physiognomically corresponding in one or certain layers only. (The conception of a 'Zwillingsformation' was introduced by Hult.)

The authors accept Warming's concept of the formation and adopt Drude's conception of 'elementary associations' (see this JournaL, 2, p. 52).

The authors are concerned also that more respect should be paid to priority in the use of the terminology of vegetation. In this matter we fear they will not meet with a great deal of sympathy. If there was one point on which all the phytogeographers present at the Brussels Congress of 1910 were agreed it was that there must be no fixation of terminology until general agreement was reached. It is perfectly clear that the failure to reach general agreement means that the development of concepts is still incomplete, that various points involved in the concepts employed are still obscure, and it is quite futile to attempt to fix nomenclature while that is the case.

Nichols, George $\mathbf{E}$. "The interpretation and application of certain terms and concepts in the ecological classification of plant communities." The Plant World, 20, 1917, pp. 305-319 and 341-353.

In sharp contrast with the authors whose papers have been noticed above Nichols takes the principle of succession as the groundwork of his classification. He regards the association as the fundamental unit of vegetation, but unlike the Swedish authors defines it as the group or community of plants occupying a common habitat, which again he defines as a unit area with an essentially uniform environment. These definitions at once introduce the difficulty of what is to be considered an 'essentially uniform' environment, as to which difference of opinion is often acute owing to the great complexity of the interactions of the factors involved. We agree with the 'floristic school' in preferring to define the association by its floristic and vegetational composition. Broadly speaking we all know an association when we see one, or rather when we have had some little experience of it and its neighbours, just as broadly speaking we all know a species in the same way. In both cases there may be differences of opinion as to just how much either should include, as to whether we should count a well-marked facies correlated with a difference of habitat as a distinct association, or whether we should separate a well-marked variety as a distinct species. We are impressing our concepts on nature in both cases, but they are good workable concepts for all that, because there is, ordinarily, a certain discontinuity between the types of well-marked associations as between the types of well-marked species. But the habitat cannot yet be defined so closely in terms of its ultimate elements, and we therefore do well to start with the unit of vegetation itself as defined by floristic composition and by structure. The author accepts Clements's consociations (alternative dominants) and societies (local aggregations of species of secondary importance), as units subordinate to the association, but considers these as floristic rather than ecological units since they are not as a rule correlated with marked differences of habitat. He also distinguishes habitat-types 